\title{
Nitrogen budgets and dissolved organic matter cycling
}

\author{
Y. Collos \\ Laboratoire d'Hydrobiologie (URA CNRS 1355), Université de Montpellier CC093, F-34095 Montpellier CEDEX 5, France
}

\begin{abstract}
Time series of biomass and nutrient levels in batch cultures of unicellular algae show widely unbalanced nitrogen budgets in some cases, with ca 0.6 to 3 times more dissolved inorganic nitrogen (DIN) consumed than particulate nitrogen (PN) produced. For those studies showing a balanced final budget, the discrepancy between DIN disappearance and PN increase does not appear to be random with time. Those trends imply excretion of dissolved organic nitrogen (DON), which can represent up to $75 \%$ of the DIN uptake, in the early part of the incubation, followed by DON uptake when DIN is exhausted. For 4 out of 5 studies in which DON was measured, this variable could account for 91 to $100 \%$ of the missing nitrogen in the final budget.
\end{abstract}

\section{INTRODUCTION}

Recent controversy about the 'vanishing ${ }^{15} \mathrm{~N}$ ' phenomenon in primary production measurements at sea (Laws 1984, Glibert et al. 1985, Price et al. 1985, Dugdale \& Wilkerson 1986, Hanson \& Robertson 1988, Eppley \& Renger 1992) dramatically outlines the necessity of balancing nitrogen budgets during incubation of water samples in order to attain a reasonable degree of internal consistency and some feel of the reliability of such measurements. Without going into the complexity of natural situations with microbial loops leading to regeneration phenomena, the problem of nitrogen balance also plagues studies of simple systems such as axenic microalgal cultures. I believe that the examination of such data can shed some light on the 'mystery of the vanishing ${ }^{15} \mathrm{~N}$ ' as well as on a related phenomenon - extracellular organic matter production - a subject of controversy in carbon flux studies (Sharp 1977, Aaronson 1978, Lancelot 1983).

\section{BIOMASS AND NUTRIENT DATA}

Literature data on biomass and nutrient levels are compiled from studies using axenic unicellular algal cultures. Only growth on inorganic nitrogen sources has been considered here. Data are available for cultures growing on organic sources but their interpretation is considerably more difficult due to the recent realization that urea is deaminated by phytoplankton, thereby releasing ammonium in the medium (Price \& Harrison 1988). The interpretation of data on incorporation of ${ }^{15} \mathrm{~N}$-labelled compounds such as these is still waiting for an adequate conceptual framework to deal with complex situations where a rapid isotopic exchange occurs between dissolved organic matter and ammonium through the phytoplankton compartment.

\section{UNBALANCED NITROGEN BUDGETS IN MICROALGAL CULTURES}

Nitrogen budgets expressed as the ratio of the change (decrease) in dissolved inorganic nitrogen (DIN) to the change (increase) in particulate nitrogen (PN) are shown in Table 1 for 13 species of unicellular algae growing in batch cultures. Ratios smaller than 1 indicate that there is more cellular $\mathrm{N}$ produced than DIN disappearing from the medium. Ratios greater than 1 mean that more DIN disappears from the medium than cellular $N$ produced in the particulate phase.

(1) Inter-Research 1992 
Table 1 Nitrogen budgets during growth of unicellular algae in axenic batch cultures. DIN: Dissolved inorganic nitrogen; PN: particulate nitrogen

\begin{tabular}{|c|c|c|c|c|}
\hline \multirow{2}{*}{ Species } & \multirow{2}{*}{$N$ source } & \multicolumn{2}{|c|}{$\triangle \mathrm{DIN} / \triangle \mathrm{PN}$} & \multirow{2}{*}{ Source } \\
\hline & & Range & Final & \\
\hline Chlorella vulgaris & $\mathrm{NH}_{4}+\mathrm{NO}_{3}$ & $0.2-2.5$ & 1.3 & Pearsall \& Loose (1937) \\
\hline Phaeodactylum tricornutum & $\mathrm{NO}_{3}$ & $1.3-5.8$ & 1.4 & Yentsch \& Vaccaro (1958) \\
\hline Dunaliella tertiolecta & $\mathrm{NO}_{3}$ & $0.4-20.0$ & 1.2 & Newell et al. (1972) \\
\hline Chroomonas sp. & $\mathrm{NO}_{3}$ & $1.1-1.6$ & 1.3 & Newell et al. (1972) \\
\hline Chlamydomonas reinhardii & $\mathrm{NO}_{3}$ & $0.2-1.8$ & 0.7 & Manny (1969) \\
\hline Nitzschia palea & $\mathrm{NO}_{3}$ & $0.7-2.3$ & 1.4 & Manny (1969) \\
\hline Cylindrotheca closterium & $\begin{array}{l}\mathrm{NO}_{3} \\
\mathrm{NH}_{4}\end{array}$ & $\begin{array}{l}1.4-3.2 \\
0.3-2.5\end{array}$ & $\begin{array}{l}2.8 \\
1.9\end{array}$ & Grant et al. (1967) \\
\hline Ditylum brightwellii & $\begin{array}{c}\mathrm{NH}_{4} \\
\mathrm{NH}_{4}+\mathrm{NO}_{3}\end{array}$ & $\begin{array}{l}0.3-1.0 \\
0.6-2.0\end{array}$ & $\begin{array}{l}0.8 \\
1.2\end{array}$ & Strickland et. al (1969) \\
\hline Biddulphia aurita & $\begin{array}{l}\mathrm{NO}_{3} \\
\mathrm{NO}_{2} \\
\mathrm{NH}_{4}\end{array}$ & $\begin{array}{l}1.2-4.0 \\
1.3-5.1 \\
0.4-2.6\end{array}$ & $\begin{array}{l}1.5 \\
1.7 \\
1.6\end{array}$ & Lui \& Roels (1972) \\
\hline Skeletonema costatum & $\mathrm{NH}_{4}+\mathrm{NO}_{3}$ & $0.1-8.8$ & 0.9 & DeManche et al. (1979) \\
\hline Thalassiosira nordenskioldii & $\begin{array}{l}\mathrm{NO}_{3} \\
\mathrm{NH}_{4}\end{array}$ & $\begin{array}{c}0.3-1.5 \\
0.3-10.0\end{array}$ & $\begin{array}{l}0.8 \\
0.6\end{array}$ & Dortch et al. (1984) \\
\hline T. weissflogii & $\begin{array}{l}\mathrm{NO}_{3} \\
\mathrm{NH}_{4}\end{array}$ & $\begin{array}{l}0.6-2.6 \\
0.6-1.5\end{array}$ & $\begin{array}{l}1.4 \\
1.4\end{array}$ & Conover (1975) \\
\hline Oscillatoria redekei & $\mathrm{NO}_{3}$ & $1.0-1.2$ & 1.1 & $\begin{array}{l}\text { Meffert \& Zimmermann- } \\
\text { Telschow (1979) }\end{array}$ \\
\hline
\end{tabular}

These are time series measurements, and for some of them, the ratio is always greater than 1 , meaning that the change in DIN is generally greater than the change in PN. In some cases, the $\mathrm{N}$ balance is far from being reached (Grant et al. 1967, Lui \& Roels 1972), with ca 1.5 to 3 times more DIN consumed than PN produced.

Values of $\triangle \mathrm{DIN} / \triangle \mathrm{PN}$ greater than 1 can be due to a number of factors. PN can be underestimated due to cellular loss during filtration (Herbland 1974, Goldman \& Dennett 1985). Excretion or leakage of $N$ compounds such as nitrite or DON can occur, and will lead to an overerestimate of DIN utilization if not taken into account in the chemical analyses. For cultures with bacteria present, $\mathrm{N}$ losses can occur due to denitrification or not measuring compounds such as $\mathrm{NO}$ or $\mathrm{N}_{2} \mathrm{O}$.
Values smaller than 1 can be due to simultaneous uptake of $\mathrm{N}$ sources other than the original one for example nitrite or DON if nitrate is the $\mathrm{N}$ source provided at the beginning of the experiment). Nitrite excretion and subsequent uptake by microalgae is known to be a widespread phenomenon (Olson et al. 1980, Anderson \& Roels 1981, Collos 1982), but the amount of nitrite produced is generally limited, so it cannot be considered as responsible for the discrepancies reported here. Ammonium is not observed to be excreted, except during organic $\mathrm{N}$ assimilation (Price \& Harrison 1988).

Therefore, DON appears to be a potential candidate to help balance the $\mathrm{N}$ budget. In fact, a number of authors (Pearsall \& Loose 1937, Yentsch \& Vaccaro

Table 2. Effect of taking into account the dissolved organic nitrogen (DON) production on the nitrogen budget during growth of unicellular algae in axenic batch cultures. Sources as in Table 1

\begin{tabular}{|c|c|c|c|}
\hline Species & $\triangle \mathrm{DIN} / \triangle \mathrm{PN}$ & $\begin{array}{l}\% \text { of difference } \\
\text { explained by } \\
\text { DON production }\end{array}$ & $\begin{array}{c}\text { DON production } \\
\text { ( } \% \mathrm{NO}_{3} \text { uptake) } \\
\text { mean (range) }\end{array}$ \\
\hline Dunaliella tertiolecta & 1.2 & 54 & $11 \quad(7-25)$ \\
\hline Chroomonas sp. & 1.3 & 91 & $22(6-50)$ \\
\hline Ditylum brightwellii & 1.2 & 100 & 41 \\
\hline Thalassiosira weissflogii & 1.4 & 100 & $30 \quad(0-78)$ \\
\hline Oscillatoria redekei & 1.1 & 100 & $6 \quad(2-13)$ \\
\hline
\end{tabular}


1958, DeManche et al. 1979, Slawyk \& Rodier 1986) assumed that the lack of $\mathrm{N}$ balance in their experiments was due to such a phenomenon. But its reality is subject to considerable controversy (Sharp 1977, Aaronson 1978, Lancelot 1983).

\section{DISSOLVED ORGANIC NITROGEN AND THE N BUDGET}

A number of studies cited in Table 1 have included measurements of DON and are summarized in Table 2. For 4 out of 5 studies, DON can account for 91 to $100 \%$ of the missing $N$ in the final budget. This could be considered as satisfactory, except for the fact that these results are generally quite difficult to assess, because the data are 'open-ended', i.e. even if DON has been measured, and even if the inclusion of this class of compounds succeeds in balancing the $\mathrm{N}$ budget, there still remains the question of whether the DON is an artefact of the measurement or not (Sharp 1977, 1984, Fuhrman \& Bell 1985, Goldman \& Dennett 1985).

\section{IN SEARCH OF THE MISSING N: TEMPORAL TRENDS IN THE NITROGEN BUDGET OF ALGAL CULTURES}

In order to answer the above question, use can be made of a few valuable data sets where the $\triangle D I N / \triangle P N$ ratio takes values both greater and smaller than 1 in a systematic manner as a function of time. Three examples will be taken, showing that the evolution of this ratio with time is neither random nor due to analytical errors.

The first data set is from the study by Yentsch \& Vaccaro (1958) on Phaeodactylum tricornutum. In order to avoid undefined values of the above ratio due to lack of change in one of the variables over a given time interval, the difference between the change in DIN and that in PN will be used. Under this configuration, positive values of the compound variable $(\triangle D I N-\triangle P N)$ mean that there is more $N$ disappearing from the solution than $\mathrm{N}$ appearing in the algal cells, and vice versa.

Fig. 1 shows that the ratio essentially takes on positive values during the early part of the incubation ( 0 to ca $30 \mathrm{~h}$ ), then takes on negative values towards the end of the experiment. The overall budget ( $t=47.5 \mathrm{~h})$, however, is not balanced (Table 1), because ca $40 \%$ of the DIN disappearing from solution is missing from the PN. Note that the $\mathrm{N}$ budget at $30 \mathrm{~h}$ was even worse, with a $\triangle D I N / \triangle P N$ ratio of 5.8 , meaning that about 6 times more $N$ had disappeared from the medium than had appeared in the cells.
Fig. 1. Phaeodactylum tricornutum. Nitrogen budget for a batch culture as a function of time. Data from Yentsch \& Vaccaro (1958). DIN: Dissolved inorganic nitrogen; PN: particulate nitrogen

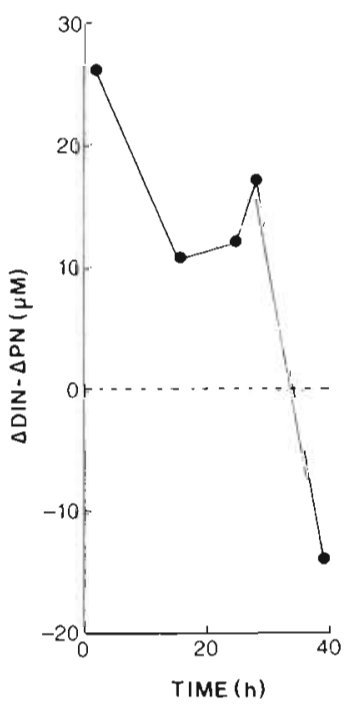

Note that such a discrepancy is very similar to the 7 fold difference recently reported between chemical and isotopic estimates of nitrate uptake by natural populations (Eppley \& Renger 1992, Wilkerson \& Dugdale 1992).

The second example is taken from DeManche et al. (1979). The lack of balance occurs during nitrate assimilation rather than during ammonium uptake. As in the first case, the dependent variable first takes on positive values, then negative ones (Fig. 2). The overall budget was 0.9 , meaning that about $10 \%$ more PN had been produced than DIN had been consumed. The difference can probably be attributed to analytical errors.

This example is a particularly interesting one in that a correctly balanced $\mathrm{N}$ budget is shown over the whole

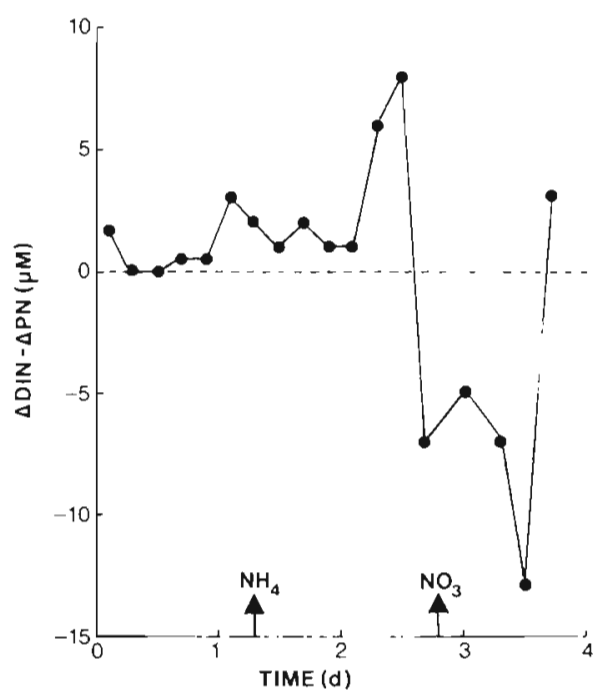

Fig. 2. Skeletonema costatum. Nitrogen budget for a batch culture as a function of time. Data from DeManche et al. (1979). DIN: Dissolved inorganic nitrogen; PN: particulate nitrogen. Arrows show exhaustion of nitrogen sources 


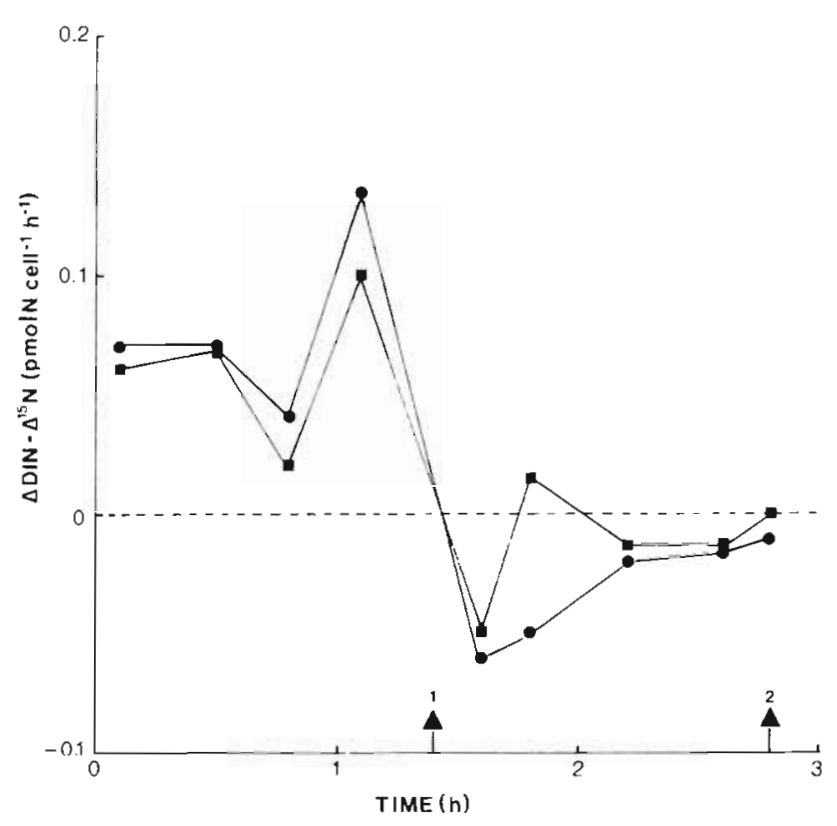

Fig. 3. Chaetoceros affinis. Nitrogen budget for a batch culture as a function of time. Data from Slawyk \& Rodier (1986). DIN: Dissolved inorganic nitrogen; ${ }^{15} \mathrm{~N}$ : nitrate uptake $(\bullet)$ or assimilation (-). Arrow 1 indicates maximum in internal nitrate. Arrow 2 indicates exhaustion of external nitrate

experiment, but a widely unbalanced one is seen over shorter time-scales. Moreover, the clear trend in having positive values during the first part and negative values later on clearly shows that these are not random variations due to analytical errors in one or the other variable.

Similar trends are shown in the study of Slawyk \& Rodier (1986) where disappearance of nitrate from the medium was compared to incorporation into the cells as estimated with the ${ }^{15} \mathrm{~N}$ tracer (Fig. 3). During the early phase of incubation, only about $40 \%$ of the decrease in nitrate could be accounted for by isotopic estimate of nitrate incorporation into biomass. Towards the end of the experiment, the reverse was true, 'the rate of isotopic uptake exceeding that of nitrate disappearance by a factor of about 5' (Slawyk \& Rodier 1986). In Fig. 3, an estimate of nitrate assimilation was used, by subtracting the rate of internal nitrate accumulation from the rate of uptake. However, the trends were not very different from those of uptake.

A possible artefact in such experiments is underestimation of PN due to cell rupture during filtration. A larger portion of PN could be lost from cells growing rapidly because of large internal nutrient pools. However, from the patterns shown in Fig. 3 , this does not seem to occur as the values of $\Delta \mathrm{DIN} / \Delta^{15} \mathrm{~N}$ are high before the internal nitrate maximum is reached.

The consistent trends between these 3 data sets suggest that the discrepancies in the $\mathrm{N}$ budget are real.
They are probably to be attributed to DON production and subsequent uptake occurring during $N$ assimilation. Recent data on a diatom species (Collos et al. 1992) tend to confirm this phenomenon.

It is generally considered that DON production results from light or nutrient shocks in cultures (Sharp 1984). This is probably the case, but such transient situations may also occur in nature, where phytoplankton cells can experience considerable variations in light (Mague et al. 1980, Marra 1980) or nutrient (Klein \& Coste 1984, Holligan et al. 1985) conditions over short time-scale. In the same way as nitrite is sometimes excreted under adverse conditions, and later reabsorbed, such a production of DON may represent an overflow mechanism in stress situations when uptake and growth are uncoupled, and DON is stored externally as a $N$ source. The real significance of this class of compounds will await further studies on their identification and the magnitude of their turnover This appears to be an important phenomenon in $\mathrm{N}$ cycling.

\section{CONCLUSION}

If the concept proposed above is adopted, then we have to accept that up to $75 \%$ of the DIN taken up can at times be excreted as DON. This compares to the $70 \%$ of extracellular carbon release in early (Fogg 1958, Fogg et al. 1965, Watt 1966, Nalewajko \& Marin 1969) and more recent (Wolter 1982, Lancelot 1983, Lancelot \& Billen 1985, Bratbak et al. 1992) studies on carbon fixation.

In natural populations, while a large portion of released dissolved organic matter can be attributed to leakage and/or excretion-egestion during grazing processes (Jumars et al. 1989, Nagata \& Kirchman 1991), these cannot account for the dramatic differences recently observed between chemical and isotopic estimates of nitrate uptake (Eppley \& Renger 1992, Wilkerson \& Dugdale 1992).

In contrast, the high values of DON production indirectly estimated here, and which have recently been observed during nitrate uptake by a diatom (Collos et al. 1992), come very close to reconciling the discrepancies mentioned above.

\section{LITERATURE CITED}

Aaronson, S. (1978). Excretion of organic matter by phytoplankton in vitro. Limnol. Oceanogr. 23: 838

Anderson, S. M., Roels, O. A. (1981). Effects of light intensity on nitrate and nitrite uptake and excretion by Chaetoceros curvisetus. Mar. Biol. 62: 257-261

Bratbak, G., Heldal, M., Thingstad, T F., Riemann, B., Haslund, O. H. (1992). Incorporation of viruses into the 
budget of microbial C-transfer. A first approach. Mar. Ecol. Prog. Ser. 83: 273-280

Collos, Y. (1982). Transient situations in nitrate assimilation by marine diatoms. 2. Changes in nitrate and nitrite following a nitrate perturbation. Limnol. Oceanogr. 27 $528-535$

Collos, Y., Döhler, G., Biermann, I. (1992). Production of dissolved organic nitrogen during uptake of nitrate by Synedra planctonica: implications for estimates of new production in the oceans. J. Plankton Res. 14: 1025-1029

Conover, S. A. M. (1975). Partitioning of nitrogen and carbon in cultures of the marine diatom Thalassiosira fluviatilis supplied with nitrate, ammonium, or urea. Mar Biol. 32: $231-246$

DeManche, J. M., Curl, H. C. Jr, Lundy, D. W., Donaghay, P. L. (1979). The rapid response of the marine diatom Skeletonema costatum to changes in external and internal nutrient concentration. Mar. Biol. 53: 323-333

Dortch, Q., Clayton, J. R. Jr, Thoresen, S. S., Ahmed, S. I. (1984). Species differences in accumulation of nitrogen pools in phytoplankton Mar. Biol. 81: 237-250

Dugdale, R. C., Wilkerson, F. P. (1986). The use of ${ }^{15} \mathrm{~N}$ to measure nitrogen uptake in eutrophic oceans; experimental considerations. Limnol. Oceanogr. 31. 673-689

Eppley, R. W., Renger, E. H. (1992). Nitrate utilization by plankton in the Equatorial Pacific March 1988 along $150^{\circ}$ W. J. geophys. Res. 97: 663-668

Fogg, G. E. (1958). Extracellular products of phytoplankton and the estimation of primary production. Rapp. P.-v. Réun. Cons. int. Explor. Mer 144: 56-60

Fogg, G. E., Nalewajko, C., Watt, W. D. (1965). Extracellular products of phytoplankton photosynthesis. Proc. R. Soc. Lond. Ser. B 162: 517-534

Fuhrman, J. A., Bell, T. M. (1985). Biological considerations in the measurement of dissolved free amino acids in seawater and implications for chemical and microbiological studies. Mar. Ecol. Prog. Ser. 25: 13-21

Glibert, P. M., Lipschultz, F., McCarthy, J. J., Altabet, M. A. (1985). Has the mystery of the vanishing ${ }^{15} \mathrm{~N}$ in isotope dilution experiments been resolved? Limnol. Oceanogr. 30: $444-447$

Goldman, J. C., Dennett, M. R. (1985). Susceptibility of some marine phytoplankton species to cell breakage during filtration and post-filtration rinsing. J. exp. mar. Biol. Ecol. 86: $47-58$

Grant, B. R., Madgwick, J., Dal Pont, G. (1967). Growth of Cylindrotheca closterium var. californica (Mereschk.) Reimann \& Lewin on nitrate, ammonia, and urea. Aust. J. mar. freshwat. Res. 18: 129-136

Hanson, R. B., Robertson, C. Y. (1988). Spring recycling rates of ammonium in turbid continental shelf waters off the southeastern United States. Cont. Shelf Res. 8: 49-68

Herbland, A. (1974). Influence de la dépression de filtration sur la mesure simultanée de l'assimilation et de l'excrétion organique du phytoplancton. Cah. ORSTOM. Sér. Océanogr. 12: 173-177

Holligan, P. M., Pingree, R. D., Mardell, G. T. (1985). Oceanic solitons, nutrient pulses and phytoplankton growth. Nature 314:348-350

Jumars, P. A., Penry, D. L., Baross, J. A., Perry, M. J., Frost, B. W. (1989). Closing the microbial loop: dissolved carbon pathway to heterotrophic bacteria from incomplete ingestion, digestion and absorption in animals. Deep Sea Res. 36: 483-495

Klein, P., Coste, B. (1984). Effects of wind-stress variability on nutrient transport into the mixed layer. Deep Sea Res. 31: $21-37$
Lancelot, C. (1983). Factors affecting phytoplankton extracellular release in the Southern Bight of the North Sea. Mar Ecol. Prog. Ser. 12: 115-121

Lancelot, C., Billen, G. (1985). Carbon-nitrogen relationships in nutrient metabolism of coastal marine ecosystems. In: Jannasch. H. W., Williams, P. J LeB. (eds.) Advances in aquatic microbiology, Vol. 3. Academic Press, London, p. $263-321$

Laws, E. (1984). Isotope dilution models and the mystery of the vanishing ${ }^{15} \mathrm{~N}$. Limnol. Oceanogr. 29: 379-386

Lui, N. S. T., Roels, O. A. (1972). Nitrogen metabolism of aquatic organisms. II. The assimilation of nitrate, nitrite, and ammonia by Biddulphia aurita. J. Phycol. 8: 259-264

Mague, T. H., Friberg, E., Hughes, D. J., Morris, I. (1980). Extracellular release of carbon by marine phytoplankton; a physiological approach. Limnol. Oceanogr. 25: 262-279

Manny, B. A. (1969). The relationship between organic nitrogen and the carotenoid to chlorophyll a ratio in five freshwater phytoplankton species. Limnol. Oceanogr. 14 $69-79$

Marra, J. (1980). Time course of light intensity adaptation in a marine diatom. Mar. Biol. Let. 1. 175-183

Meffert, M. E., Zimmermann-Telschow, H. (1979). Net release of nitrogenous compounds by axenic and bacteria-containing cultures of Oscillatoria redekei (Cyanophyta). Arch. Hydrobiol. 87: 125-138

Nagata, T., Kirchman, D. L. (1991). Release of dissolved free and combined amino acids by bactivorous marine flagellates. Limnol. Oceanogr. 36: 433-443

Nalewajko, C., Marin, L. (1969). Extracellular production in relation to growth of four planktonic algae and of phytoplankton populations from Lake Ontario. Can. J. Bot. 47: 405-4.13

Newell, B. S., Dalpont, G., Grant, B. R. (1972). The excretion of organic nitrogen by marine algae in batch and continuous culture. Can. J. Bot. 50: 2605-2611

Olson, R. J., SooHoo, J. B., Kiefer, D. A. (1980). Steady-state growth of the marine diatom Thalassiosira pseudonana. Uncoupled kinetics of nitrate uptake and nitrite production. Plant Physiol. 66: 383-389

Pearsall, W. H., Loose, L. (1937). The growth of Chlorella vulgaris in pure culture. Proc. R. Soc. Lond. Ser. B. 121. $451-501$

Price, N. M., Harrison, P. J. (1988). Uptake of urea C and urea $N$ by the coastal diatom Thalassiosira pseudonana. Limnol. Oceanogr. 33: 528-537

Price, N. M., Cochlan, W. P., Harrison, P. J. (1985). Time course of uptake of inorganic and organic nitrogen by phytoplankton in the Strait of Georgia: comparison of frontal and stratified communities. Mar. Ecol. Prog. Ser. $27: 39-53$

Sharp, J H. (1977). Excretion of organic matter by marine phytoplankton: do healthy cells do it? Limnol. Oceanogr. 22: 381-399

Sharp, J. H. (1984). Inputs into microbial food chains. In: Hobbie, J. E., Williams, P. J. LeB. (eds.) Heterotrophic activity in the sea. NATO conference series IV, Marine Sciences, Vol. 15. Plenum Press, New York, p. 101-120

Slawyk, G., Rodier, M. (1986). Glutamine synthetase activity in Chaetoceros affinis (Bacillariophyceae): comparison with other estimates of nitrogen utilization during nutrient perturbation. J. Phycol. 22: 270-275

Strickland, J. D. H., Holm-Hansen, O., Eppley, R. W., Linn, R. J. (1969). The use of a deep tank in plankton ecology. I. Studies of the growth and composition of phytoplankton. crops at low nutrient levels. Limnol. Oceanogr 14:23-34 Watt, W. D. (1966). Release of dissolved organic material from 
the cells of phytoplankton populations. Proc. R. Soc. Lond Ser. B 164: 521-551

Wilkerson, F. P., Dugdale, R. C. (1992). Measurement of nitrogen productivity in the equatorial Pacific. J. geophys. Res 97: $669-679$

This article was submitted to the editor
Wolter, K. (1982). Bacterial incorporation of organic substances released by natural phytoplankton populations. Mar. Ecol. Prog. Ser. 7: 287-295

Yentsch, C. S., Vaccaro, R. F. (1958). Phytoplankton nitrogen in the oceans. Limnol. Oceanogr. 3: 443-448

Manuscript first received: May 12, 1992

Revised version accepted: November 3, 1992 